\title{
Emerging Trends in Textile Industry
}

\author{
Satish Kumar R* \\ Department of Marketing Area, IFIM Business School, India
}

Submission: June 14, 2018; Published: July 17, 2018

*Corresponding author: Satish Kumar R, Department of Marketing Area, IFIM Business School, Bangalore, India, Email: satish.kumar@ifimbschool.com

\section{Introduction}

The textile industry in India is highly labor intensive and fragmented. Textile industry is growing with increasing demand from both domestic and international markets. The industry is contributing 4 percent to the country's GDP. Textile Industry contributes 17 percent to the country's exports, and 21 percent employment. It is the second largest employer after agriculture, is expected to employ around 50 million people in the next five years. India has rich natural resources such as cotton, jute and silk. Indian textile products are known for their designing, embellishment and craft. The industry at present is growing at 12 percent. Indian textile industry presently enjoys a share of $4.7 \%$ in world market of textiles and clothing. India is the largest producer of jute in the world, the second largest producer of silk, the third largest in cotton and second largest in cellulosic fibres, and the fifth largest in synthetic fibres/yarns.

Textile industry is considered as a self-reliant industry, from the production of raw materials to the delivery of finished products, with substantial value-addition at each stage of processing; it is a major contribution to the country's economy [1].

Indian textile products are popular across the world due to the versatility, quality and design of these products. The major retailers include Dockers, Bed, Bath and Beyond, J.C.Penney, Nautica, Target, Kohl's Liz, Calvin Klein, Sprit, Marks \& Spencer, GAP, United Colors of Benetton, Mango, Zara and Dillard's etc.

The Indian textile industry is as diverse as the country is and as complex an entity. Indian population is around 1.2 billion out which around 30 percent are from middle class. Indian middleclass population is more than the population of U.K, Italy and France put together. Since India is among the emerging countries with high GDP growth rate may foreign investors are investing in India. Today textile products are not only sold through retail outlets but also through e-Commerce platforms such as Flipkart, Myntra, Snapdeal, Amazon, and eBay. Recently major shares of Flipkart was acquired by Wal-Mart. Indian textile industry is an organized, decentralized sector and down the line, there are weavers, artisans as well as the farmers. The spectrum of technology is widespread, right from handmade to semi- mechanical and highly sophisticated information- and microprocessor-based technologies. The processing sector is one of the significant stage in the value chain contributing to the end user an array of properties like easy care and wrinkle free finishes besides aesthetic value addition in terms of colors, motifs and designs. The value addition at this stage is immense, with a range of other functional finishes like hydrophilic, stretch-back effect, oil and water repellent, and peace effect, to name a few. Specialty chemicals have played a significant role in the production of fibres and textiles. Awareness of chemical reactions, polymer sciences and understanding complex biochemical reactions have resulted in what we see as a dramatic shift in the minds of a processor [2].

\section{Global apparel market}

Table 1: Global Apparel Market Size (US\$ Bn.).

\begin{tabular}{|c|c|c|c|c|}
\hline S. No & Region & $\mathbf{2 0 1 5}$ & CAGR & Projected 2025 \\
\hline 1 & EU 28 & 350 & $1 \%$ & 390 \\
\hline 2 & USA & 315 & $2 \%$ & 385 \\
\hline 3 & China & 237 & $10 \%$ & 615 \\
\hline 4 & Japan & 93 & $1 \%$ & 105 \\
\hline 5 & India & 59 & $12 \%$ & 180 \\
\hline 6 & Brazil & 56 & $5 \%$ & 90 \\
\hline 7 & Russia & 40 & $3 \%$ & 55 \\
\hline 8 & Canada & 25 & $2 \%$ & 30 \\
\hline & Others & 510 & $4 \%$ & 750 \\
\hline & Total & 1685 & $4 \%$ & 2600 \\
\hline
\end{tabular}

Source: Wazir Research and Analysis

The current global apparel market is worth US\$ 1.7 trillion, and it amounts to 2 percent of the world's GDP. EU, USA \& China are the world's largest apparel markets with a combined share of approximately 54 percent. The top eight apparel consuming nations form a dominating share of 70 percent of the global apparel market size (Table 1).

\section{Conclusion}

The global apparel market is expected to reach US\$ 2.6 trillion in 2025 with growth projection at $4 \%$. The major drivers 
of the growth are the developing nations such as India and China. China will be the number one apparel market expected to reach US $\$ 378$ bn. 2025 followed by India at around US $\$ 121$. The growth is mainly due to the growing demand in both domestic and global markets. The Indian textile companies have to adopt latest technologies and come out with innovative product designs to be competitive in the global market.

\section{References}

1. http://wazirin/textile-apparel-insights/industry-report/

2. Bharadwaj MR, Noor Afza (2017) Emerging Trends in Textile Industry in India.

Your next submission with Juniper Publishers will reach you the below assets

- Quality Editorial service

- Swift Peer Review

- Reprints availability

- E-prints Service

- Manuscript Podcast for convenient understanding

- Global attainment for your research

- Manuscript accessibility in different formats

( Pdf, E-pub, Full Text, Audio)

- Unceasing customer service

Track the below URL for one-step submission https://juniperpublishers.com/online-submission.php 